\title{
Postępy w leczeniu chorych na hemofilie
}

\author{
Advances in the treatment of patients with hemophilias
}

\author{
Jerzy Windyga \\ Klinika Zaburzeń Hemostazy i Chorób Wewnętrznych, Instytut Hematologii i Transfuzjologii, Warszawa
}

\begin{abstract}
Streszczenie
Celem pracy jest omówienie wybranych zagadnień zwiazanych z postępem leczenia hemofili w ostatnich latach, w tym wprowadzenia do praktyki klinicznej nowych, zmodyfikowanych koncentratów czynników krzepnięcia, udanej terapii genowej u chorych na cięzka postać hemofilii B oraz udanej dtugoterminowej profilaktyki krwawień u pacjentów na cieżka postać hemofilii A powiktana inhibitorem czynnika VIII o wysokim mianie.
\end{abstract}

Słowa kluczowe: hemofilia, przedłużony okres półtrwania, terapia genowa, inhibitor, profilaktyka

Hematologia 2015; 6, 1: 97-102

\begin{abstract}
This paper aims to discuss selected advances made recently for treating hemophilias consisting of the following; introducing new modified clotting factor concentrates for clinical use, successful gene therapy in patients with severe hemophilia $B$ and successful long-term bleeding prevention in patients with severe hemophilia complicated by a high titre of factor VIII inhibitor.
\end{abstract}

Key words: hemophilia, extended half-life, gene therapy, inhibitor, prophylaxis

Hematologia 2015; 6, 1: 97-102

\section{Wprowadzenie}

Ostatnie dekady są najbardziej fascynującym okresem w historii badań nad leczeniem wrodzonych skaz krwotocznych. Sklonowanie genu czynnika krzepnięcia IX (FIX, factor IX) w 1982 roku i genu czynnika krzepnięcia VIII (FVIII, factor VIII) w 1984 roku umożliwiło opracowanie technologii produkcji rekombinowanych czynników krzepnięcia, których istotną przewagą nad osoczopochodnymi czynnikami krzepnięcia jest niższe ryzyko przeniesienia cząstek zakaźnych $[1,2]$. Ale przewaga leków rekombinowanych nie ogranicza się do większego bezpieczeństwa ich stosowania. Rekombinowane cząsteczki mogą być poddawane genetycznym modyfikacjom, których wynikiem jest większa aktywność, mniejsza immunogenność, a także dłuższy okres biologicznego półtrwania zmodyfikowanego białka [2, 3]. W 2014 roku w Stanach Zjednoczonych, Kanadzie i kilku innych krajach zarejestrowano dwa rekombinowane czynniki krzepnięcia o przedłużonym działaniu, które zapewniają skuteczną profilaktykę krwawień u pacjentów z hemofilią A i B, choć są wstrzykiwane o 30-80\% rzadziej niż standardowe (niemodyfikowane) czynniki krzepnięcia [4].

Ostatecznym celem w leczeniu hemofilii nie jest jednak skuteczna profilaktyka, lecz całkowite wyleczenie choroby, co można osiągnąć poprzez skuteczną terapię genową. W 2011 roku opublikowano po raz pierwszy wstępne, pozytywne wyniki badań nad terapią genową hemofilii B u ludzi [5].

Adres do korespondencji: Jerzy Windyga, Klinika Zaburzeń Hemostazy i Chorób Wewnętrznych, Instytut Hematologii i Transfuzjologii, ul. Indiry Gandhi 14, 02-776 Warszawa, tel.: 22349 61 58, faks: 2234961 59, e-mail: jwindyga@ihit.waw.pl 
W 2014 roku wyniki te potwierdzono w kolejnej publikacji [6]. Co ważne, w 3-letniej obserwacji nie wykazano późnych objawów toksyczności terapii genowej w grupie 10 pacjentów objętych badaniem. Terapia genowa zaczyna się stawać jedną $z$ dostępnych opcji terapeutycznych w hemofilii B.

Największym problemem współczesnego leczenia hemofilii jest inhibitor niedoborowego czynnika krzepnięcia, czyli alloprzeciwciała pojawiające się w odpowiedzi na leczenie substytucyjne i prowadzące do neutralizacji wstrzykiwanego czynnika krzepnięcia [7]. Profilaktyka krwawień u chorych na hemofilię powikłaną inhibitorem wydaje się jedyną atrakcyjną opcją leczenia w przypadku ciężkiego przebiegu skazy i niepowodzenia bądź przeciwwskazań do zastosowania leczenia eradykującego inhibitor (immunotolerancji). W ostatnich latach dostarczono ważnych dowodów naukowych wskazujących na bezpieczeństwo i skuteczność długoterminowej profilaktyki krwawień $z$ zastosowaniem koncentratu aktywowanych czynników zespołu protrombiny (aPCC, activated prothrombin complex concentrate) u pacjentów $\mathrm{z}$ hemofilią powikłaną inhibitorem [8].

\section{Czynniki krzepnięcia o przedłużonym okresie biologicznego półtrwania}

Prace nad czynnikami krzepnięcia o przedłużonym działaniu trwają od kilkunastu lat. Korzyść z wytworzenia takich czynników jest oczywista - możliwość zmniejszenia częstości dożylnych wstrzyknięć w długoterminowej profilaktyce krwawień u pacjentów z ciężką hemofilią A i B. W 2014 roku w Stanach Zjednoczonych, Kanadzie, Australii i Japonii zarejestrowano dwa koncentraty o przedłużonym czasie działania: 1) rekombinowany czynnik VIII połączony $z$ fragmentem $\mathrm{Fc}$ immunoglobuliny G (rFVIII-Fc, recombinant factor VIII fusion to FcIG) - efraloctocog alfa oraz 2) rekombinowany czynnik IX połączony $z$ fragmentem Fc immunoglobuliny G (rFIX-Fc, recombinant factor IX fusion to $F c I G$ ) - eftrenonacog alfa [4]. Rejestracja obu leków była poprzedzona intensywnymi badaniami klinicznymi, w których udowodniono skuteczność i bezpieczeństwo obu koncentratów w profilaktyce i leczeniu krwawień u młodocianych i dorosłych chorych na hemofilię A i B, uprzednio leczonych (PTP, previously treated patients) koncentratami czynników krzepnięcia $[9,10]$.

Szczególnie obiecujące są wyniki uzyskane u pacjentów $z$ hemofilią B. Okres biologicznego półtrwania rFIX-Fc wynosi 82,1 godziny. W przypadku podawaniu rFIX-Fc w dawce 20 jednostek międzynarodowych (IU, international units)/kg mc. co 7 dni lub 40 jm./kg mc. co 10 dni albo 100 jm./ /kg mc. co 14 dni u wielu pacjentów $\mathrm{z}$ ciężką hemofilią B udaje się stale utrzymywać aktywność FIX w osoczu powyżej $1 \mathrm{jm} . / \mathrm{dl}$, czyli „przekształcić” hemofilię ciężką w umiarkowaną, dla której charakterystyczne jest niewystępowanie samoistnych krwawień. Innymi słowy, u tych pacjentów jest szansa zmniejszenia liczby dożylnych wstrzyknięć FIX w długoterminowej profilaktyce krwawień o 50-80\% przy zachowaniu co najmniej tej samej skuteczności, co zapewniona dzięki obecnie stosowanym rekombinowanym koncentratom FIX wstrzykiwanym 2 razy w tygodniu. Żaden $z$ pacjentów otrzymujących rFIX-Fc w ramach prób klinicznych nie wytworzył inhibitora wobec czynnika IX. W opinii niektórych ekspertów fragment Fc immunoglobuliny może się wręcz przyczyniać do zmniejszenia immunogenności FIX (także FVIII) [2, 4].

Mniej spektakularne wyniki dotyczące rFVIII-Fc tłumaczy się wiązaniem wstrzykniętego FVIII $z$ czynnikiem von Willebranda (vWF, von Willebrand factor), który determinuje tempo klirensu FVIII (zarówno endogennego, jak i egzogennego) [4]. Okres biologicznego półtrwania rFVIII-Fc wynosi $19 \mathrm{~h}$, co oznacza, że jest około 1,5-krotnie dłuższy w porównaniu ze standardowymi rFVIII. W praktyce oznacza to, że odstępy między wstrzyknięciami u pacjenta $z$ ciężką hemofilią A poddanego długoterminowej profilaktyce krwawień można wydłużyć do 3-5 dni, a u wybranych chorych $z$ bardzo korzystnymi parametrami farmakokinetycznymi - nawet do 7 dni. W badaniu klinicznym 3. fazy roczna częstość krwawień (ABR, annualized bleeding rate) u pacjentów otrzymujących regularne wstrzyknięcia rFVIII-Fc co 3 dni, 2 razy w tygodniu, co 4 dni i co 5 dni wyniosła odpowiednio $0,0,0,0,2,0$ i 2,0 [3]. Są to obiecujące wyniki, zwłaszcza gdy weźmie się pod uwagę, że badaniem objęto pacjentów należących do grupy PTP, u których nierzadko występowała istotna artropatia hemofilowa.

W badaniach klinicznych u PTP wykazano ponadto, że nowo zarejestrowane koncentraty są skuteczne i bezpieczne w osłonie hemostatycznej zabiegów chirurgicznych, a docelowa aktywność niedoborowego czynnika krzepnięcia w okresie okołooperacyjnym powinna być taka sama, jak w przypadku stosowania standardowych koncentratów FVIII i FIX. Amerykańska Agencja ds. Żywności i Leków (FDA, Food and Drug Administration) zaleca stosowanie testów koagulacyjnych z użyciem kwasu elagowego do monitorowania aktywności rFIX-Fc oraz odpowiednich testów 
Tabela 1. Zmodyfikowane koncentraty czynników krzepnięcia

Table 1. Modified clotting factor concentrates

\begin{tabular}{|c|c|c|}
\hline Czynnik krzepnięcia & Modyfikacja & $\begin{array}{l}\text { Korzyść kliniczna/status } \\
\text { wg www.clinicaltrials.gov }\end{array}$ \\
\hline \multicolumn{3}{|l|}{ FIX } \\
\hline rFIX-Fc & Białko fuzyjne z FclG & $\begin{array}{l}\text { Rejestracja poza Europą (m.in. w Stanach } \\
\text { Zjednoczonych). } T_{1 / 2} \text { wydłużony 3-5-krotnie }\end{array}$ \\
\hline rFIX-FP & Białko fuzyjne $z$ albuminą & $\begin{array}{l}\text { Zakończona } 3 \text {. faza badań klinicznych. } \mathrm{T}_{1 / 2} \\
\text { wydłużony 3-5-krotnie }\end{array}$ \\
\hline N9-GP & 40 kDa PEG połączony z peptydem aktywacyjnym & $\begin{array}{l}\text { Zakończona 3. faza badań klinicznych. } \\
\mathrm{T}_{1 / 2} \text { wydłużony }>\text { 5-krotnie }\end{array}$ \\
\hline \multicolumn{3}{|l|}{ FVIII } \\
\hline rFVIII-Fc & Białko fuzyjne z FclG & $\begin{array}{l}\text { Rejestracja poza Europą (m.in. w Stanach Zjed- } \\
\text { noczonych). } T_{1 / 2} \text { wydłużony 1,8-krotnie }\end{array}$ \\
\hline BAX855 & $\begin{array}{l}20 \text { kDa PEG dołączony do nieswoistej lizyny } \\
\text { w FL-FVIII }\end{array}$ & $\begin{array}{l}\text { W 3. fazie badań klinicznych. } T_{1 / 2} \text { wydłużony } \\
\text { 1,5-krotnie }\end{array}$ \\
\hline BAY94-9027 & 60 kDa PEG dołączony do cysteiny & $\begin{array}{l}\text { Zakończona } 3 \text {. faza badań klinicznych. } \mathrm{T}_{1 / 2} \\
\text { wydłużony 1,7-krotnie }\end{array}$ \\
\hline N8-GP & 40 kDa PEG dołączony do 21 aa domeny B & $\begin{array}{l}\text { W 3. fazie badań klinicznych. } T_{1 / 2} \text { wydłużony } \\
\text { 1,5-krotnie }\end{array}$ \\
\hline \multicolumn{3}{|l|}{ rhFVIII-SC } \\
\hline $\begin{array}{l}\text { (recombinant human } \\
\text { FVIII-single chain) }\end{array}$ & Pojedynczy łańcuch FVIII & $\begin{array}{l}\text { W 3. fazie badań klinicznych. Zwiększone } \\
\text { powinowactwo do vWF }\end{array}$ \\
\hline \multicolumn{3}{|l|}{ rFVIII-huCL } \\
\hline $\begin{array}{l}\text { (recombinant FVIII- } \\
\text { human cell line) }\end{array}$ & Produkcja w ludzkich liniach komórkowych & $\begin{array}{l}\text { W 3. fazie badań klinicznych. Zachowana } \\
\text { glikozylacja natywnego ludzkiego FVIII }\end{array}$ \\
\hline \multicolumn{3}{|l|}{ FVIIa } \\
\hline rFVIIa-FP & Białko fuzyjne z ludzką albuminą & W 3. fazie badań klinicznych \\
\hline rFVIIa-RB & Białko syntetyzowane przez transgeniczne króliki & $\begin{array}{l}\text { Zwiększona aktywność swoista. } T_{1 / 2} \text { wydłużony } \\
\text { 3-4-krotnie }\end{array}$ \\
\hline
\end{tabular}

FIX (factor IX) - czynnik IX; FcIG — fragment Fc immunoglobuliny G; T $1 / 2$ - okres biologicznego półtrwania; FP (fusion protein) — białko fuzyjne; PEG — polietylenoglikol; kDa - kilodaltony; FVIII (factor VIII) - czynnik VIII; rFVIla (recombinant activated factor VII) - rekombinowany aktywowany czynnik VII; vWF (von Willebrand factor) - czynnik von Willebranda

chromogennych i koagulacyjnych do monitorowania rFVIII-Fc [4].

Rejestracja rFIX-Fc i rFVIII-Fc w Europie musi być poprzedzona przeprowadzeniem badań klinicznych w grupie uprzednio leczonych pacjentów pediatrycznych. Takiego wymogu nie stawia FDA, dlatego dopuszczone do obrotu w Stanach Zjednoczonych leki nie są jeszcze dostępne w Europie. $\mathrm{W}$ tabeli 1 przedstawiono nowe koncentraty czynników krzepnięcia (w większości o przedłużonym działaniu), które już dopuszczono do obrotu oraz te, które prawdopodobnie zostaną wprowadzone do praktyki klinicznej w najbliższych latach. Różni producenci wykorzystali różne sposoby wydłużenia okresu biologicznego półtrwania czynników krzepnięcia [3, 4]. Oprócz łączenia białka $\mathrm{z}$ fragmentem $\mathrm{Fc}$ immunoglobuliny zastosowano także pegylowanie czynników krzepnięcia, które polega na połączeniu białka wiązaniem kowalencyj- nym $z$ polietylenoglikolem (PEG), a także łączenie czynnika krzepnięcia $z$ albuminą $[11,12]$. Oprócz czynników krzepnięcia o przedłużonym działaniu w próbach klinicznych testuje się także zmodyfikowane białka o zbliżonym okresie biologicznego półtrwania do okresów półtrwania standardowych czynników krzepnięcia. Przykładem jest rFVIII produkowany w komórkach ludzkich (rFVIII-hcl, recombinant FVIII-human cell line), a zatem zachowujący wzór glikozylacji charakterystyczny dla natywnego czynnika VIII [13]. Potencjalną zaletą rFVIII-hcl ma być mniejsza immunogenność w porównaniu ze standardowymi rFVIII. Ciekawą koncepcją jest także produkcja rFVIII o strukturze jednołańcuchowej (rhFVIII-SC, recombinant human FVIII-single chain) wykazującej większe powinowactwo do vWF [12]. Przyczynia się to do nawet 2-krotnego wydłużenia okresu biologicznego półtrwania rFVIII. 


\section{Terapia genowa w hemofilii B}

W grudniu 2011 roku ukazały się wyniki najważniejszej, jak dotąd, próby klinicznej, w której oceniano skuteczność i bezpieczeństwo terapii genowej hemofilii B [5]. Autorzy zastosowali nowy wektor na bazie adenopodobnego wirusa (AAV, adenoassociated virus) serotypu 8 (AAV8) u 6 pacjentów $z$ ciężką hemofilią B. W testach przedklinicznych badacze dowiedli, $\dot{z}$ e wysoki poziom transdukcji można osiągnąć po wstrzyknięciu nowego wektora niosącego gen ludzkiego czynnika IX (AAV8-FIX) do żyły obwodowej i że nie jest konieczne podawanie AAV8-FIX do tętnicy wątrobowej (co było niezbędne w pierwszej próbie klinicznej prowadzonej przed laty i zakończonej niepowodzeniem; wówczas zastosowano inny wektor - AAV2). Pacjenci otrzymali trzy różne dawki AAV8-FIX (2 - małą, 2 - średnią i 2 - dużą). $Z$ badania wykluczono osoby $z$ obecnymi przeciwciałami przeciwko AAV8. Wszyscy chorzy bardzo dobrze znieśli infuzję wektora; nie stwierdzono działań niepożądanych. U 4 pierwszych chorych (dwie pierwsze kohorty) zaobserwowano zwiększenie aktywności koagulacyjnej czynnika IX (FIX:C, factor IX coagulation activity) do $1-3 \mathrm{jm} . / \mathrm{dl}$. Pacjenci z ostatniej kohorty zanotowali wzrost FIX:C do, odpowiednio, 8 i 6 jm./dl. Jednak u 1 chorego wystąpił istotny wzrost stężenia aminotransferaz (> 200 jm./1), który wymógł zastosowanie kortykosteroidów (60 mg prednizolonu/d.). Kortykosteroidy pozwoliły unormować stężenie aminotrasferaz, ale wartość FIX:C zmniejszyła się do $2 \mathrm{jm} . / \mathrm{dl}$. U kolejnego pacjenta także zaobserwowano wzrost stężenia aminotransferaz, ale znacznie mniejszy niż u poprzedniego chorego. Bardzo szybko włączone kortykosteroidy pozwoliły znormalizować aminotransferazy, a FIX:C ustabilizował się na poziomie $6 \mathrm{jm} . / \mathrm{dl}$. Testy laboratoryjne (IFN gamma ELISPOT) przeprowadzone u obu pacjentów wykazały, że przyczyną wzrostu stężenia aminotransferaz i obniżenia FIX:C była odpowiedź immunologiczna ustroju przeciwko białkom kapsydowym wektora wirusowego. Odpowiedź ta zależy od klonu komórek T CD8+ swoistych dla kapsydu AAV. Po transdukcji hepatocyta peptydy kapsydu są eksponowane na powierzchni komórki przez MHC (major histocompatibility complex) klasy I, dzięki czemu są rozpoznawane przez komórki T CD8+ swoiste dla kapsydu, co wyzwala mechanizm eliminacji transdukowanego hepatocyta. Ponadto wektor jest także wychwytywany przez komórki prezentujące antygen, które $z$ kolei prezentują go w kompleksie z MHC klasy II, prowadząc do aktywacji komórek pomocniczych CD4+ i produkcji cytokin. Niepodważalnym osiągnięciem Nathwaniego i wsp. [5] było wykazanie, że kilkutygodniowe podawanie prednizolonu w dawce $60 \mathrm{mg} /$ dobę jest w stanie wygasić odpowiedź immunologiczną ustroju i przywrócić ekspresję transdukowanego genu.

Ostatnio Nathwani i wsp. [6] przedstawili wyniki dłuższej (mediana 3,2 roku) obserwacji 10 chorych na hemofilię B poddanych terapii genowej -6 opisanych w poprzedniej publikacji oraz 4 włączonych później, u których zastosowano wyłącznie duże dawki wektora wirusowego $\left(2 \times 10^{12} / \mathrm{kg} \mathrm{mc}\right.$.). Pojedyncza dożylna infuzja wektora spowodowała utrzymujący się przez cały czas obserwacji wzrost aktywności FIX $\mathrm{u}$ wszystkich 10 chorych na ciężką hemofilię B. U pacjentów, którym wstrzyknięto dużą dawkę wektora, średnia wartość ( \pm odchylenie standardowe [SD, standard deviation]) FIX:C w osoczu wynosi $5,1 \pm 1,7 \mathrm{jm} . / \mathrm{dl}$. U tych pacjentów liczba krwawień oraz zużycie koncentratu rFIX zmniejszyły się o 90\%. U 4 spośród 6 pacjentów $z$ grupy otrzymującej dużą dawkę wektora, między 7. a 10. tygodniem po jego infuzji, zaobserwowano wzrost stężenia aminotransferazy alaninowej do wartości 36-202 jm./1 (średnio 86 jm./l), ale po zastosowaniu prednizolonu (początkowo $60 \mathrm{mg} / \mathrm{d}$., ale $z$ szybkim zmniejszaniem dawki leku), w ciągu 2-35 dni (średnio 5 dni), wartość aminotransferazy alaninowej się znormalizowała. Nie zanotowano żadnych późnych powikłań terapii genowej.

Dalsze wysiłki badaczy będą zmierzały do potwierdzenia obserwacji Nathwaniego i wsp. [14] oraz rozszerzenia wskazań do terapii genowej hemofilii B o pacjentów zakażonych ludzkim wirusem niedoboru odporności (HIV, human immunodeficiency virus) i wirusem wątroby typu C (HCV, hepatitis C virus) oraz tych, u których wykryto przeciwciała przeciwko AAV. W ostatnim przypadku rozwiązaniem może być zastosowanie pustych kapsydów AAV2, które chronią kapsydy AAV8 zawierające gen kodujący FIX, poprzez związanie obecnych $\mathrm{w}$ krwiobiegu pacjenta przeciwciał przeciwko AAV [15]. Bardzo interesujące są też badania nad alternatywnymi wektorami, na przykład lentiwirusowymi. Kolejnym krokiem w rozwoju badań nad terapią genową powinno być zapoczątkowanie prób klinicznych u pacjentów $z$ hemofilią A. Niestety, dziś wiadomo, że o sukces w terapii genowej hemofilii A będzie znacznie trudniej niz $\mathrm{w}$ hemofilii $\mathrm{B}$ - przede wszystkim z powodu wielkości cDNA FVIII oraz silniej odpowiedzi immunologicznej ludzkiego organizmu wobec FVIII [14]. 


\section{Długoterminowa profilaktyka krwawien w hemofilii A powikłanej inhibitorem}

Wśród chorych na hemofilię A powikłaną inhibitorem FVIII potencjalnymi kandydatami do długoterminowej profilaktyki krwawień $z$ zastosowaniem koncentratów czynników krzepnięcia omijających inhibitor są pacjenci, u których nie udało się uzyskać stanu tolerancji immunologicznej (IT, immune tolerance) lub u których odstąpiono od indukcji immunotolerancji (ITI, immune tolerance induction) $z$ powodu niekorzystnych czynników rokowniczych uzyskania IT, a ponadto: 1) doznają częstych krwawień bądź 2) przebyli krwawienie zagrażające życiu (np. śródczaszkowe). Długoterminową profilaktykę należałoby także zastosować u pacjentów poddawanych ITI wciąż doznających krwawień, gdyż bez niej uzyskanie IT może być okupione bardzo wysoką ceną, na przykład kompletnie zniszczonych struktur stawowych. $\mathrm{Na}$ konieczność prewencji krwawień w hemofilii powikłanej inhibitorem wskazują wyniki ostatnio opublikowanej pracy, której amerykańscy autorzy wykazali, że wystąpienie inhibitora FVIII w przebiegu hemofilii A zwiększa ryzyko zgonu wywołanego krwawieniem [16].

Badanie Pro-FEIBA jest pierwszym prospektywnym, randomizowanym badaniem typu cross-over służącym ocenie skuteczności aPCC $\left(\mathrm{FEIBA}^{\circledR}\right)$ $\mathrm{w}$ długoterminowej profilaktyce krwawień [8]. Czas obserwacji w badaniu wynosił 15 miesięcy. Składało się z 3 faz: 1) trwającej 6 miesięcy profilaktyki (85 j./kg mc. $\pm 15 \%) 3$ razy w tygodniu, ale nie w następujących po sobie dniach, 2) trwającego 3 miesiące okresu wash-out oraz 3) trwającego 6 miesięcy okresu leczenia „na żądanie”. O rozpoczęciu badania od fazy profilaktyki lub od fazy leczenia „na żądanie” decydowała randomizacja. Badaniem objęto 34 chorych na ciężką hemofilię A powikłaną inhibitorem FVIII o wysokim mianie, w wieku ponad 2 lat, przy czym 26 ukończyło badanie i zostało poddanych końcowej analizie. Liczba krwawień do stawów (średnio/6 miesięcy $4,2 v .10,8)$ oraz liczba wszystkich krwawień (średnio/6 miesięcy 5,0 $v .13,1$ ) była statystycznie istotnie mniejsza $\mathrm{w}$ okresie profilaktyki niż w okresie leczenia „na żądanie” ( $\mathrm{c}<0,0001)$. Kolejność randomizacji do profilaktyki i leczenia ,na żądanie” nie wpływała na wyniki. Leczenie było dobrze tolerowane; zanotowano tylko jedno poważne działanie niepożądane związane $z$ lekiem (odczyn uczuleniowy). W okresie obserwacji profilaktyka spowodowała zmniejszenie o $61 \%$ liczby krwawień do stawów i o $62 \%$ liczby wszystkich krwawień w porównaniu z okresem leczenia „na żądanie”. U 16 pacjentów zaliczonych do grupy dobrze odpowiadających na profilaktykę (zmniejszenie liczby krwawień w okresie profilaktyki $>50 \%$ w porównaniu z okresem „na żądanie”) stwierdzono także istotną poprawę parametrów jakości życia zależnej od zdrowia w okresie profilaktyki (kwestionariusz SF-36) [17].

Wyniki badania Pro-FEIBA nie zmieniają strategii postępowania w hemofilii powikłanej inhibitorem; wciąż nadrzędnym celem pozostaje eradykacja inhibitora i wytworzenie IT. Jak jednak wykazały wyniki badania IITS (International Immune Tolerance Study), nie więcej niz $70 \%$ chorych na hemofilię A powikłaną inhibitorem FVIII o wysokim mianie uzyskuje IT [18]. Co 3. pacjent $z$ hemofilią A powikłaną inhibitorem FVIII o wysokim mianie będzie zatem wymagał stosowania koncentratów omijających inhibitor. Długotrwała profilaktyka z zastosowaniem aPCC staje się dla takich osób prawdopodobnie optymalną opcją terapeutyczną, albowiem stwarza szansę zarówno uniknięcia krwawień zagrażających życiu, jak i zmniejszenia, a u wybranych pacjentów nawet całkowitego wyeliminowania, krwawień do stawów.

\section{Piśmiennictwo}

1. Ehrlich H.J., Wong W.Y., Ewenstein B.M. i wsp. Development of novel treatment options for patients with haemophilia. Hämostaseologie 2013; 33 (supl. 1): S36-S38.

2. Pipe S.W. Hemophilia: new protein therapeutics. Hematology Am. Soc. Hematol. Edu. Program 2010; 2010: 203-209.

3. Oldenburg J., Albert T. Novel products for haemostasis - current status. Haemophilia 2014; 20 (supl. 4): 23-28.

4. Powell J.S. Lasting power of new clotting proteins. Hematology Am. Soc. Hematol. Edu. Program 2014; 2014: 355-363.

5. Nathwani A.C., Tuddenham E.G., Rangarajan S. i wsp. Adenovirus-associated virus vector-mediated gene transfer in hemophilia B. N. Engl. J. Med. 2011; 365: 2357-2365.

6. Nathwani A.C., Reiss U.M., Tuddenham E.G.D. i wsp. Long-term safety and efficacy of factor IX gene therapy in hemophilia B. N. Engl. J. Med. 2014; 371: 1994-2004.

7. Kempton C.L., Meeks S.L. Toward optimal therapy for inhibitors in hemophilia. Blood 2014; 124: 3365-3372.

8. Leissinger C., Gringeri A., Antmen B. i wsp. Anti-inhibitor coagulant complex prophylaxis in hemophilia with inhibitors. N. Engl. J. Med. 2011; 365: 1684-1692.

9. Powell J.S., Pasi K.J., Ragni M.V. i wsp. Phase 3 study of recombinant factor IX Fc fusion protein in hemophilia B. N. Engl. J. Med. 2013; 369: 2313-2323.

10. Mahlangu J., Powell J.S., Ragni M.V. i wsp. Phase 3 study of recombinant factor VIII Fc fusion protein in severe hemophilia A. Blood 2014; 123: 317-325.

11. Pasut G., Veronese F.M. State of the art in PEGylation: the great versatility achieved after forty years of research. J. Control. Release 2012 ; 161: 461-472. 
12. Schulte S. Innovative coagulation factors: albumin fusion technology and recombinant single-chain factor VIII. Thromb. Res. 2013; 131 (supl. 2): S2-S6.

13. Sandberg H., Kannicht C., Stenlund P. i wsp. Functional characteristics of the novel, human-derived recombinant FVIII protein product, human-cl rhFVIII. Thromb. Res. 2012; 130: 808-817.

14. High K.A. The gene therapy journey for hemophilia: are we there yet? Hematology Am. Soc. Hematol. Edu. Program 2012; 375-381.

15. Wright J.F. Manufacturing and characterizing AAV-based vectors for use in clinical studies. Gene Ther. 2008; 15: 840-848.
16. Walsh C.E., Soucie J.M., Miller C.H. i wsp. Impact of inhibitors on hemophilia A mortality in the United States. Am. J. Hematol. 2015; 90: 400-405.

17. Hay C.R.M., DiMichele D.M. The principal results of the International Immune Tolerance Study: a randomized dose comparison. Blood 2012; 119: 1335-1344.

18. Gringeri A., Leissinger C., Cortesi P.A. i wsp. Health-related quality of life in patients with haemophilia and inhibitors on prophylaxis with anti-inhibitor complex concentrate: results from the Pro-FEIBA study. Haemophilia 2013; 19: 736-743. 